\title{
Early Childhood Development (ECD) Centre Leadership during COVID-19 in Urban and Rural Areas in South Africa
}

\author{
Keshni Bipath \\ Orcid iD: https://orcid.org/0000-0003-0588-9905
}

\author{
Adebunmi Aina \\ Orcid iD: https://orcid.org/0000-0001-9417-1510
}

\section{Abstract}

Good quality education is usually considered a great 'equaliser', yet bridging the inequality gaps in South Africa seems to be an impossible task. Effective Early Childhood Development (ECD) programmes have a positive influence on children's development and school readiness by providing valuable educational and social experiences. In response to the coronavirus disease 2019 (COVID-19) pandemic, ECD operators were instructed by the Department of Social Development (DSD) to close on 18th March 2020 to prevent the spread and acceleration of infection. This lockdown highlighted the plight of ECD operators who were not able to collect fees from caregivers, impacting the payment of salaries and other fixed costs. The livelihoods of the majority of ECD operators are sensitive to broader economic impacts that affect household income. Media articles and reports were used to explore the government's response to the ECD sector in South Africa. Narrative vignettes were utilised to analyse the lived experiences of four ECD principals from two rural and two urban contexts. Contextresponsive leadership is presented as a lens through which to view the leadership experiences of the four principals. Findings show that government departments undervalued and neglected the ECD workforce. However, while the article was being written (during October 2020), signs of the government hearing the voices of concerned practitioners and providing financial relief 
became visible. The COVID-19 pandemic had placed ECD in the spotlight through court cases and signed petitions and accentuated the differences in the context-responsive leadership behaviour between principals in rural and urban areas.

Keywords: ECD centre principals, COVID-19, context-responsive leadership, South African government, ECD reforms, rural and urban ECD centres

\section{Introduction}

The coronavirus disease 2019 (COVID-19) pandemic, has led to huge public health and economic challenges worldwide (Yoshikawa et al. 2020). In response to the pandemic, Early Childhood Development (ECD) operators (including ECD centres, playgroups, day mothers and other early learning programmes) in South Africa were instructed by the Department of Social Development (DSD) to close on 18th March 2020 to prevent the acceleration of the spread of the disease. Owing to the lockdown, the majority of ECD operators have not been able to collect fees from parents, income which they rely on to pay salaries and other fixed costs. The parents' fees are essential for ECD operators, and their income is sensitive to the broader economic impacts on household income (BRIDGE et al. 2020). The report issued by BRIDGE et al. was based on a survey of 3952 ECD operators conducted in mid-April 2020.

It was estimated that as many as 30000 ECD operators serving poor communities in South Africa ran the risk of permanent closure as a result of the COVID-19 crisis. This means that up to 175000 people would be left unemployed, and 1.5 million children would be without early learning services or a day care facility offering adequate nutrition. In turn, their caregivers would be unable to participate in the labour market, which is critical for economic recovery (BRIDGE et al. 2020). From the onset, there was the general view that this closure would have a tremendous impact on schools, teachers and students (Almanthari et al. 2020). However, unintended consequences amongst the vulnerable socio-economic ECD centres might be the worst yet. Spaul and Van der Berg (2020) argue that learning deficits amongst children as a result of school closures, are likely to widen the inequality gap further in South Africa. 
Despite the South African Constitutions intentions to 'heal the divisions of the past and establish a society based on democratic values, social justice and fundamental human rights' (Republic of South Africa (RSA) 1996), the legacy of apartheid continues to constrain efforts to address poverty and inequality in South Africa:

The Millennium Development Goals are closely interconnected in their impact on the rights of the young child. Poverty, maternal and child survival, nutrition, health, protection from violence, abuse and exploitation, gender equality and human development have short- and long-term consequences for the rights of young children, with implications for future generations, as poverty cycles are reproduced (United States Department of Health and Human Services, 2010: 4).

The provision of good quality education in ECD is considered a great 'equaliser', yet bridging the inequality gaps in South Africa seems to be an impossible task. South Africa remains a highly unequal society, where the majority of the people live in poverty and a minority has employment. Inequalities persist, as schools in richer communities can afford to employ more or better trained teachers than no-fee schools which serve poorer communities (Equal Education 2009).

\section{Early Childhood Development in South Africa: The Great 'Equaliser'}

Globally, there is increasing awareness of the value of early childhood care and education as the foundational basis for upward mobility in any nation's educational ladder, especially in developing countries of Africa, including South Africa. Early Childhood Development has been recognised and identified as a critical nodal point for the country's social and economic transformation and development (Bipath \& Joubert 2016). In South Africa, several legislative initiatives related to ECD were enacted to ensure that young children have equal access to quality early childhood education. The new policies were set out in the Department of Welfare White Paper of 1997, the Education White Paper 5 on ECD in 2001 (Department of Education 
(DoE) 2001); the National Integrated ECD Policy in 2015; the Early Childhood Quality Programme for babies from birth to four years in 2015, and the South African National Curriculum Framework (NCF) for children from birth to four years in 2017. When the new Policy on Minimum Requirements for Programmes Leading to Qualifications in the Higher Education for Early Childhood Development (ECD) Educators was released on 31st March 2017, improvement of the ECD sector became an achievable mission.

However, these policies mentioned seemed to have made promises amidst an unpromising context in South Africa and have threatened disarray rather than progress. Young children in vulnerable communities still have limited access to quality education and there is concern that not enough is being done to address this challenge. With the COVID-19 lockdown and the maltreatment of the ECD operators in the lower socio-economic areas, the achievement of a high quality ECD workforce seemed to have been even more disrupted and the vision of a good quality ECD sector seemed to have become unachievable.

According to the DSD (2015: 39), 'access to Early Childhood Development (ECD) programmes is inequitable with the poorest children having the least access'. Others like Mbarathi et al. (2016), in line with the DSD (2015), assert that many ECD centres especially in the rural areas, do not have resources for quality teaching and learning because they are not registered to qualify for a subsidy. Mbarathi et al. (2016) and Baloyi and Makhubela (2018) argue these under-resourced ECD centres lack government support because they do not meet the required DSD registration standards. As such, ECD practitioners are not provided with good quality training by government, to teach young children. Furthermore, the DSD provides some registered ECD facilities with a subsidy of R17 per child (DSD, 2020), varying each year per province. In this regard, provision of ECD services is inequitable, and young children in the vulnerable communities do not receive good quality education.

Little research has focused on ECD and leadership practices, or the predominant contextual variables in which they operate. Even less research has focused on the manner in which government departments work to recognise, understand and shape the contextual influences found within the ECD context. The COVID-19 pandemic was an unforeseen challenge and the literature review that follows consists of the most recent report on ECD 
in South Africa during the pandemic. Thus, the purpose of this article was to better understand how major contextual factors influence the broader government and centre-based leadership during a national pandemic.

This study focuses on government's response to all ECD centres during the pandemic as well as the lived experiences of ECD centre principals in rural and urban areas during the COVID-19 lockdown, to identify the leadership response to the COVID-19 context. The COVID-19 pandemic had the potential of revealing leadership capacity with regard to the government and ECD leaders' responses to an unexpected situation. Therefore, the questions used in this study were as follows:

- How did the government respond to the closure and re-opening of ECD centres in rural and urban areas?

- What were the differences between the lived experiences of the four ECD principals in rural and urban areas during the COVID-19 lockdown?

Context-responsive leadership is presented as a lens through which to view the responses from government and the leadership challenges and opportunities of the four ECD principals. Articles and reports regarding the ECD sector were used in gauging the context-responsive leadership of the government departments and the plight of the ECD workforce after COVID19. The study encompasses six sections: 1) an introduction; 2) ECD: the great 'equaliser'; 3) context-responsive leadership; 4) a literature review presented as a means of describing the government's response to ECD sector through articles and reports, and the methodological processes that underpinned the study. The responses of leadership were obtained through the ECD principals' stories about how they reacted to the lockdown procedures. Thereafter, discussion and conclusions led to the formulation of practical implications for the study.

It is hoped that the outcomes of this study would add to the impetus of government departments taking on their leadership responsibility for the country's most vulnerable citizens - young children. It is also expected that the recommendations would improve the conditions of the ECD workforce and provide good quality infrastructure, resources and training for the ECD centres in South Africa, especially those situated in rural areas. 


\section{Context-responsive Leadership}

Context-responsive leadership is conceived as practical wisdom in action, which reveals a complex mix of knowledge, skills, and dispositions appropriately deployed by effective leaders as they engage in fluid conversations with dynamic situational variables. 'Context-responsive leadership is expressed through action, the way the leader behaves, not any one predisposed style consisting of de-contextualized qualities or leader actions' (Bredeson et al. 2011: 20). Louis et al. (2010: 94) acknowledged that 'Leadership success depends greatly on the skill with which leaders adapt their practices to the circumstances in which they find themselves, their understanding of the underlying causes of the problems they encounter, and how they respond to those problems'. Similarly, Hallinger (2016) states that a good leader adapts leadership practices to the requests, prospects and restrictions within their context. This implies that leaders should be aware of the people's needs and should also be able to engage the right strategies in tackling these needs. Consequently, leaders should be able to offer the appropriate responses that address their contextual situation.

The context could include 'the broader organisational and environmental setting within which school and the school leaders exist' (Hallinger 2016: 3). Concerning this study, the broader organisational setting consists of the government departments and the officials, while the environmental context refers to the community settings where the centre exists such as the socio-economic status of people which it serves, rural or urban location, registration status of the centre, the available amenities and unemployment/ employment status of people in the community. The understanding of the context variables should help the leaders to provide for the appropriate needs of the people in the context. According to Bredeson et al. (2011), good leaders should mainly utilise the combination of their resources to respond to the contextual challenges. Similarly, Noman et al. (2018) note that leadership practices should resonate with their unique contextual realities. Furthermore, the context-responsive view of leadership more aptly accounts for the principals anticipatory and responsive engagement with their respective contexts. Principals who employ context-responsive leadership strategies recognise that contexts vary and that they can both enable and constrain their behaviour. In rural areas, principals need to rise to the challenges and be innovative to achieve success. 


\section{Government's Response to the ECD Sector}

\section{Utter Disregard for ECD from the Government during the COVID-19 Lockdown}

The social and education needs of South Africa's youngest and most vulnerable children is fundamental to economic prosperity, political stability, the advancement of democracy and nation building (Atmore 2021: 4). Atmore (2021:4) goes on to question 'whether politicians will choose to prioritise young children or whether they will again only kiss babies at election time rather than putting young children first in the years ahead' The ECD sector seems like 'an irritating cousin for the government, one that they do not have the capacity or interest to deal with, so they have just pretended it doesn't exist' (Bassingthwaighte 2020: 4). The ECD sector is an example of a sector that has not been adequately catered for from the outset. From the day that school closures in relation to COVID-19 were announced, the utter disregard for the ECD sector has been a bizarre situation to behold, according to Bassingthwaighte (2020). The ECD sector is in the process of moving from the Department of Social Development (DSD) to the Department of Basic Education (DBE). However, it seems, is that the DBE does not yet have the capacity to deal with the sector and the DSD has long since given up its duty to support it effectively.

Since the lockdown began, the President and other Ministers have referred to industries across the board several times. However, by October 2020), the President, Minister of Education and the Minister of Social Development had not mentioned the operations of the ECD centres at any time. Seated in 'No Man's Land' (Bassingthwaighte 2020), ECD seemed to be regarded as a nuisance and frustration for both departments (DBE and DSD), with neither having the capacity or energy to deal with it. Vorster (2020) agrees with this claim by stating that the key factors for the disruption and destruction included poor planning by the DSD, slow response times, government's lack of appreciation for the realities facing South African families, the importance of ECD (despite it being the DSD's flagship project), and the historical problems related to the registration of ECD centres. Farber (2020) quotes Proudlock, a senior researcher at the Children's Institute (University of Cape Town), who argued that 'The decision to close down the school feeding scheme during lockdown and hope that a new food parcel programme would reach over nine million children, was not based on 
evidence'. She emphasised that before the government had made decisions to close down services during a disaster or crisis, they should have at least evaluated the impact that it would have on vulnerable children and women.

\section{Complicated Registration Process for ECD Centres}

The ECD funding model works in such a way that funding is only available to ECD centres that are registered with the DSD. At the same time, Leshoele (2016) claims that the registration process of ECD centres with the DSD is full of red tape and contains unreasonable requirements. This complicated registration process prevents a higher percentage of ECD centres from claiming government subsidies. The BRIDGE report found only $45 \%$ were registered with the South African Revenue Service (SARS), 13\% as companies with the Companies and Intellectual Property Commission (CIPC); only $35 \%$ of their workforce was registered with the Unemployment Insurance Fund (UIF), with most salaries below minimum wage. Operators of ECD programme and their workforce thus found themselves unable to access many of the relief schemes on offer because of their informal business model.

These unregistered ECD centres have no other choice but to rely on the fees paid by the parents. The implication is that ECD centres with enrolled learners whose parents are mostly non-paying parents (especially the rural centres), will not be able to offer quality early childhood care and education which the government aims to achieve. This would unfortunately mean that the ECD programme operators most at risk of closure, were situated in the poorest communities and were providing an essential early learning service and safe day care option to the most vulnerable children in South Africa.

Errors made during government's lockdown planning will be viewed as serious (Vorster 2020). It took the DSD three months following the COVID-19 closure of ECDs to even begin disclosing re-opening plans. Vorster (2020) goes on to write that by 20th June 2020, community adverts were full of nursery schools selling off their play equipment and resources, as many had exhausted their financial resources and had also given up hope of recovery. This is in reference to the 'resourced' operations! Most ECD programmes are located in poorer communities and they ran out of resources many weeks before. Plans for re-opening were followed by a 60-page 'Standard operating procedure (SOP)' for ECD programme centre operators, 
knowing full well that most of them are unqualified or underqualified. Centres had to ensure that they all had appropriate personal protective equipment (PPE), kept safe social distancing, used hand-sanitisers often and ensured the wiping and cleanliness of learning equipment, playrooms and toilets. In rural ECD centres, ensuring social distancing was a problem due to lack of space and thus it seemed that a permanent lockdown was inevitable in most disadvantaged ECD centres. The COVID-19 pandemic has emphasised prevailing 'disparities and risks for children, families, and communities of colour and those living in poverty' (Fortuna et al. 2020: 445).

\section{The Lack of Professionalisation in the ECD Sector}

The ECD sector is dominated by female employees who work very long hours and are generally unappreciated by the community. Furthermore, these practitioners have to contend with the lack of professionalisation of the sector, which results in them being treated unprofessionally and remunerated below average salaries (Atmore et al. 2012) To ensure good quality outcomes in the ECD sector, Urban (2014) states that the ECD centre employees, the practices, their appropriate qualifications and working conditions are key predictors to strengthen the sector. These key factors should be considered positively so that the ECD sector can be seen as a professional entity of the education sector. However, the ECD sector is facing reluctance by government to address the needs of the ECD practitioners. This is an indirect refusal to uphold and promote children's rights to basic quality education, which goes against their constitutional rights as enshrined in the Bill of Rights of the Constitution of the Republic of South Africa (1996).

On 30th July 2020, the DSD Minister Zulu stated that R1.3 billion out of the President's COVID-19 Economic Stimulus Package would be allocated to the short-term employment of 36000 youth compliance monitors for ECD programmes (DoMore Foundation (23/10/2020). This was deemed to be an injustice to the ECD workers, as there was no indication of relief for them in the form of financial aid. Without urgent financial aid, more than 175000 long-term ECD workforce jobs were likely to be decimated as a result of the pandemic and the national lockdown. Members of the ECD community and supporters of their plight protested against the announcement made by Minister Lindiwe Zulu. 


\section{A Sigh of Relief for the ECD Workforce}

In support of the ECD practitioners across the country, a tremendous effort was made by the \#SaveOurECDWorkforce Campaign in August 2020. On 22nd October 2020, as this article was being written, news of the Employment Protection Support Scheme was a welcome relief for the ECD sector. Practitioners then knew that their calls for support had not gone unheard (Vorster 2020).

On 15th October 2020, the President announced his 'Public investment in a mass employment strategy'. Included in this announcement was the COVID-19 Temporary Employment Protection Support Scheme, which promised to provide relief for 83333 ECD practitioners working at ECD programmes until March 2021 (a maximum of six months). This intervention would assist ECD practitioners, many of whom would otherwise be retrenched (DoMore Foundation 2020). Although the financial support was only R760 per person per month, the fact that it targeted eligible registered and unregistered centres is a significant step towards supporting the sector more effectively. The voices of the practitioners were finally heard, although a report published on 22 nd October 2020 states that the proposed relief would not cover all 175000 practitioners that the campaign originally aimed to reach (Farber 2020). This was an important step forward for the sector which would needs its implementation to be carefully monitored.

\section{The ECD Reform Movement}

Dissatisfied with unattainable registration requirements, a complicated dual registration process, pro-poor mechanisms in the Children's Act that are not used and major gaps in the legislation that prevent the ECD policy from being properly implemented, ECD practitioners banded together with the South Africa Childcare Association and other interested ECD stakeholders and formed a very comprehensive reform movement (DoMore Foundation (27/04/2020). ECD practitioners complained that the legal system was not serving the children and communities in poor areas. It is estimated that there are over six million children of ECD centre-going age (excluding Grade R) in South Africa, with the majority of these children living in poverty. However, 3.2 million children, which represents more than 50\%, are not accessing any ECD programmes. Of those who do access some form of ECD 
programme, 2.9 million children are in unregistered programmes, with only 800654 children enrolled at registered centres. Only $626574(25 \%)$ of the children who need support are receiving subsidised learning (Mndende 27 October 2020).

On 27th October 2020, ECD practitioners in South Africa called on parliament to implement five reforms within the ECD sector. A signed petition followed a court case by the South Africa Childcare Association. The petition called on Parliament to implement the following five reforms.

- Reform 1: We need a one-step registration process for ECD providers. Different types of ECD programme providers including playgroups, toy libraries and home-based care must be regulated differently. A one-size-fits-all approach is not appropriate.

- Reform 2: All children attending any type of ECD programme should be able to access the early learning subsidy if they need it.

- Reform 3: Simpler, adequate health, and safety and programme standards must be in place and must be assessed through one process.

- Reform 4: It must be made clear that you can get conditional registration if you can't meet all the registration requirements. Members of the Executive Council (MECs) must support providers servicing poor communities to meet registration requirements and they must be required to report to the Minister on progress achieved.

- Reform 5: The infrastructure needs of the sector must be supported. Current providers (including on private land) should be able to receive support and municipalities must be required to provide for and maintain sufficient and appropriate ECD infrastructure in their regions (Real Reform for ECD 2020:1).

The five reforms show the desperation of the practitioners for centres to registered, for access to subsidised ECD education for all children, improved health and safety standards and procedures, and support for infrastructure in order to provide quality ECD to all South African children. It is hoped that the reforms will be approved by parliament and that 
government officials will realise the urgent need to take responsibility for the young children who will be the future generation of citizens and leaders.

\section{Research Methodology}

This study adopted a narrative inquiry as an underpinning methodology. Using narrative inquiry, the government's response to the ECD sector and the leaders' experiences such as ECD centre principals in this study, are explored. It was discovered that their experiences are real and change over time and in different social contexts and environments (Caine et al. 2013). According to Dwyer and Emerald (2017), narratives are an important and potent channel through which people can voice their experiences. In this study, the ECD principals shared their experiences in the form of narrative vignettes. Four narrative vignettes are used to show the peculiarities of the ECD principals' experiences during the COVID-19 school lockdown.

Vignettes are defined as 'short stories about hypothetical characters in specified circumstances, and the interviewee is invited to respond to those situations' (Finch 1987). A distinct strength of the vignette is that it allows researchers, when working cross-culturally, to understand the peculiarities of different cultures (Torres 2009). Wallander (2009) also added that vignettes could help researchers to identify and describe specific contexts accurately, concretely, and with relatively minimal resources such as time, funds and personnel. This study aimed to understand the government responsiveness to the ECD sector and the ECD centre leadership during COVID-19 in the rural and urban areas of Pretoria, South Africa. It is essential to understand the leadership performance of the ECD centres in their 'specific context' and using vignettes was considered most appropriate. The use of vignettes differs and depends on the design of the research, data collection, and presentation of vignettes (Bradbury-Jones et al. 2014). In this study, to collect data, open-ended questions in the form of a narrative journal were posed to the participating ECD principals to obtain their experiences in the form of stories regarding the COVID-19 lockdown. Principals from two ECD centres in the rural areas and two ECD centres in the urban areas of Pretoria, South Africa, were selected. The two ECD centres in the rural areas was not registered with the DSD, while one centre from the urban areas was registered, and the second one was not registered. Emails were initially sent to the ECD principals explaining the purpose of the study and the research 
ethics applied. The principals in the urban centres responded to the emails and agreed to be part of the research process. The principals in the rural centres did not respond to the emails, which required the researcher to travel to the rural centres to seek their consent. All necessary COVID-19 safety protocols such as social distancing, wearing a face mask and hand sanitising, were observed during data collection.

Regarding data presentation and discussion, the researchers engaged a particular format of the vignette, where the components of the story notes are interposed with analysis (Dwyer \& Emerald 2017). The relevant part of the story, as stated by the participants, was presented, and the analysis flowed from the perspective of the participants (Coulter \& Smith 2009). In analysing and discussing the participants' stories, literature such as the ECD policies, articles on ECD centre management during COVID-19 and responsiveleadership were considered as data sets. However, the participants' voice (narrative) was the focal point. Considering research ethics, the real identity of the centres and principals were not disclosed, hence pseudonyms were used as follows: the principal of rural ECD centre 1 is referred to as $M$ White, the principal of rural ECD centre 2 is Ms Yellow, the principal of the urban registered ECD centre is Ms Green, and the principal of the urban unregistered ECD centre is Ms Purple. The four vignettes were collated from the collected data through the narrative inquiry. The ECD principals shared their experiences regarding their leadership roles during the COVID-19 lockdown. In this study, two stages of analysis were employed. The first stage of the analysis was the construction of the vignette, which was described as narrative analysis (Polkinghorne 1995) and 'storying of the evidence' (Dwyer \& Emerald 2017: 19). The second stage of analysis involved each of the vignettes being subjected to critical analysis of the storylines to answer the research question underpinning the study.

\section{Four Vignettes: ECD Principals' Context-responsive Leadership}

Four vignettes were presented, starting with the narrative of rural ECD centre principal one's (Ms White's) response to the centre closure due to the pandemic, followed by rural ECD centre principal two's (Ms Yellow's) financial struggle and fear during school closure. The urban ECD principals, 
one from a registered centre (Ms Green) and the other from an unregistered ECD centre (Ms Purple), provided their lived-experiences during the COVID-19 closing and re-opening of centres.

\section{Vignette 1: Plans and Vision for the Centre Disrupted}

This vignette depicts rural ECD centre 1 . This centre is situated in a rural area in Itireleng, Pretoria. The centre is not registered with the DSD, hence did not get any form of assistance from the government. Ms White is completing her diploma in Early Childhood Education; she is 35 years old. She started operating the centre in March 2014. She began with two of her own children and three of her neighbours' children. Ms White uses two rooms from her apartment as a crèche. She employs one practitioner and a cook who assist her in running the centre. Ms White uses her front yard as the outdoor playground with a slide, a swing and a space where children can play. The playrooms are decorated with numbers, alphabet pictures and creative art activities done by the children. Ms White had 18 enrolled children before the COVID-19 lockdown. She described her personal experience regarding COVID-19 lockdown as shocking and devastating:

I have parents promising to bring their children to the centre so that the centre can grow, but the COVID-19 school lockdown disrupted the plans and vision that I have for the centre. The problem is that we do not have any support from the government due to the community we are. People from the department [DSD] do not come to visit us. We tried to get registered with the Department of Social Development but [had] no luck. So, the COVID-19 school lockdown worsens the situation. We only rely on the fees paid by the parents. It is worse now that parents are not bringing their children, nor paying fees. The problem with the parents here is that they are not working; they rely on grant money that they receive from the government. So, now that their children are at home, they use the money to buy food for themselves and the children. Due to this, we do not get any form of support from the parents. The challenge now is that nothing is coming from anywhere, so this is a trying and challenging time for us as a centre. When I heard that the schools and business[es] have to close down because of the virus, we informed the 
parents [of this news] verbally when they brought their children to the centre. The parents were not happy, but I told them that we have to obey the government to stop the spreading of the virus. During the lockdown, some parents lost their jobs, so when we were told to re-open the centre, the parents could not bring their children back to the centre for two reasons. First, parents are afraid that their children will contact [contract] the virus and secondly, some parents are no longer in the position to pay because they lose [lost] their jobs. We are not opened [open] yet because not a single child had [has] returned to the centre. [I] Am feeling very bad, am so challenged. I don't even know what to do because when school is open, it will look as if we are just starting to run the centre from afresh.

Ms White's experiences regarding the COVID-19 lockdown are typical of most centres in rural areas. The ECD policies have been developed to support ECD centres to improve the quality of early childhood care and development. Her experience regarding the COVID-19 lockdown reveals that much still needs to be done to bridge the gap between the 'haves' and the 'have-nots'. She also highlighted the lack of support from government departments. However, her 'I don't even know what to do' statement has highlighted her vulnerability as an underqualified and inexperienced practitioner. Urban (2014) views quality from a systematic perspective and acknowledge the importance of ECD actors such practitioners, district officials and government departments and their interaction to establish quality in implementing ECD policy on a day-to-day basis. The ECD policy situation in South Africa is complex due to the disjuncture in the provision of ECD services by different departments (Davids et al. 2015). The three departments are DSD, DBE and the Department of Health (DoH), with the Department of Women, Children and People with Disabilities (DWCPD) playing a monitoring role. Perhaps the fact that ECD is in 'no man's land', no 'man' or department has taken responsibility for the monitoring and support of the ECD centres and their functionality. However, it must be noted that this principal blames the lack of support from government, yet she has had six years of experience running the centre and it is still not registered. Situated in a rural context, the principal also highlighted the fact that parents are unemployed and the need for food and basic human necessities supersedes the need to send their children back to the centre. 


\section{Vignette 2: Financial Struggle and Fear due to Lack of Understanding of COVID-19 Procedures}

This vignette is about Ms Yellow's experience during the school lockdown. Ms Yellow is the principal of the rural ECD centre 2. She is 42 years old and has an ECD diploma. However, Ms Yellow has had only four years of experience in ECD. She had 25 children in her centre before the COVID-19 lockdown and employed two practitioners. Ms Yellow owns the building of the centre, so this is a relief for her regarding running and administrative expenses. She said that her experience during the COVID-19 school lockdown is surrounded with fear because she does not have a full understanding of the situation; she has had to discharge the children and close down the school because the government said all schools should close. Ms Yellow's experience is shared below:

My main problem since the school has been closed is financial challenges because we were unable to pay salaries - with no form of support from the government or support from the parents during the COVID-19 school lockdown. Learners have not returned after the opening of the schools. We are unable to meet all the things that we are expected to provide, like sanitiser, face masks and the rest. When the centre was closed, we communicated with parents through WhatsApp, and we encouraged them to sing with the kids and play with them at home. As a centre, we could not provide any resources for the parents to use with their children at home. Although I was aware that the government sent out learning materials for parents to use with their children while at home, I did not get any. That has been our problem, and we do not get support from the government; maybe it is because of our location. The food vendors all struggle to come here. It's like we are at the end of the world. Now that we are told to open, I sent a message to the parents, and only two learners returned. To ensure the safety of the learners and staff, I put sanitiser at the entrance to be used before entering the centre. I also put water and soap outside. Like I said, parents are not bringing their children back, so I even told my staff to stay at home; no more children returned to school. Most parents lose [lost] their jobs, so they complain about money. Another thing is 
that parents are afraid that their children might contract the virus if they bring them back to the centre. I think the government should pay more attention to their citizens living in rural areas. The government should enlighten people more about this virus, especially people in the rural areas and also meet people's needs because you can't keep people at home without making provision for them. This increases more crime in this area. The school lockdown will affect young children because all that they have learnt, they will forget. Even if they come back to school, we have to start afresh. So that will affect the pace of learning.

Ms Yellow's story indicates that there is no appropriate response from the ECD sector leadership regarding the COVID-19 lockdown context. She did not get any form of financial support to pay her staff, nor received any learning materials that could be sent to the parents of her enrolled children. The experiences of Ms Yellow shows that the quality of learning of the young children while staying at home is affected, as there are no play and stimulation resources provided for the parents. Only two parents brought their children back after re-opening. Secondly, the economic status of her staff was hampered because she has been unable to pay salaries since the centre shut its doors for the lockdown. The loss of salaries and jobs is a double blow for the young children in the rural areas; as a result, an appropriate response to mitigate the problems is expected from the ECD leadership, especially towards the ECD centres in the rural communities. Yoshikawa et al. (2020: 191) note the effects of the pandemic on early ECD and state that 'attention to the most vulnerable populations requires unprecedented coordination of ECD services, owing to these groups' even more challenging contexts'. Adeleke (2020) states that some homes in Nigeria did not have the resources required for appropriate child development and learning. He suggests that there should be policy and practice support for home-schooling from government and agencies: 'Examples of efficient home-school practice should be publicised to show that it is a quality alternative to regular schools' (Adeleke 2020: 67). These ideas would also be beneficial for parents in a South African setting. However, it should be noted that this qualified principal had only four years of experience. Her inexperience could have been the reason behind her not seeking information from either the internet or from colleagues about the types of resources 
available to send to parents to support home learning. It was also seen from her experiences that she waited for the government response and did not realise her role and responsibility as a principal in seeking assistance from others in the ECD sector.

\section{Vignette 3: Informing Parents and Guiding Children into the New Normal}

Vignette 3 highlighted the experiences of Mrs Green, a 53-year-old, qualified foundation phase teacher, who has been teaching since 1989. She is currently the Academic Principal at an urban, registered ECD centre in Pretoria East. She has 280 children in her ECD centre. The uncertainty of COVID-19 became a reality when she and four other co-workers tested positive for the novel coronavirus. She said:

I realised that we are in for a bumpy ride, although we followed the protocols to the finest detail and me being the appointed COVID-19 person at the school: the virus still crept up on us. It was so frustrating to battle COVID-19 and still have to face the battle at the school via Zoom and WhatsApp, getting everything up and running, informing parents and guiding children into this new normal. We have been very fortunate that most of our parents and children are healthy and are back, and happy to fulfil their purpose.

Regarding support from government, we were absolutely relieved to get assistance from government with regards to salaries. We were fortunate enough to get TERS [Temporary Employer/ Employee Relief Scheme funds] since lockdown. DSD that came for [an] inspection [and] also exceeded expectations in how they handled the new normal. Our school passed with flying colours. The support from parents was also very good. Parents that lost their jobs were sponsored by other parents that weren 't affected by this pandemic. The support in terms of protocols and new rules were not at all opposed by anyone, they were too relieved that the school could re-open. 
The major challenge experienced was that we lost 53 children because parents could not afford school fees or lost their jobs. Unfortunately, quite a few of the parents have lost their jobs and could not pay, but the majority were still able to pay fees during lockdown [alert] level 5 [the strictest level].

We immediately started with Google Classroom; the teachers did their prep as usual and loaded short videos where they explained the themes. Our classed carried on as usual and the children had to return their tasks. Everything was printed out and kept in their files. The whole spectrum was covered. We used resources such as Video Google classes and WhatsApp videos, where the teacher still kept in touch with the parents of the children they teach.

We became aware of the numerous online resources that could be sent to parents that would assist in stimulation of their children. We also made our own resources. The teachers made a small space where they filmed themselves to keep it interactive with the children. We asked the parents to utilise resources at home to create something beautiful; we also provided the full theme and the children could carry on, at their own pace.

The above narrative describes an ideal situation during COVID-19. Ms Green was an effective leader and engaged with dynamic situational variables created by the pandemic, resulting in her changing her practices. The urban registered centre did not seem to have problems and it seems that the context-responsive principal was very proactive and showed her skills by getting organised, applying for TERS and then keeping parents aware of the activities they could create to ensure effective and appropriate learning and development of the children. Being in an urban area, where most parents had well-paying permanent jobs, this ECD centre had the support of the government funding, TERS, and was able to be complementary to the government and its procedures. In some cases, parents who could afford school fees were supported by those parents that could. It seems that at this centre, COVID19 created a bond between the parents and the principal and teachers decided to use alternative methods of teaching. The children and their parents were respected and this principal responded adequately and speedily to ensure that 
the children were not neglected. The different ways of keeping in touch with parents enhanced her creative leadership style as well as her knowledge of building trusting relations with her clients, the parents.

\section{Vignette 4: A Virtual 4-day Programme Sent Out to Parents}

Mrs Purple, the principal of the unregistered urban ECD centre, has been teaching for 31 years. She is qualified with a 4-year Higher Diploma in Education. She has taught in both private and government schools in a variety of roles from educator (Grade R to Grade 10), to HOD (Junior phase), and acting deputy principal of a primary school (350 pupils). She opened up a Playschool of 15 pupils in 2003.

Although her school is unregistered, she has done an online course in COVID-19 and its procedures, as she is a member of the Independent Schools Association of Southern Africa (ISASA) and a teachers' union. She has kept up-to-date with the pandemic and the protocols needed. She has implemented the COVID-19 SOPs at her centre. When asked about support from government, she said:

I received nothing financially and too many mixed messages via the media. Regarding support from parents, I have received no payment during the lockdown. Financially, I am way behind in my bond etc., and I was able to pay for food and electricity and my assistant's salary for two months. I still find it difficult to financially cope as we only have six pupils who have returned. I find pupils' parents are still the biggest problem as they often forget their masks, etc. But I am strict and don't allow them on the premises. I also found the initial outlay for cleaning products to be expensive.

When asked about how she kept in touch with parents she said:

My first communication was via our school WhatsApp group and email. I then moved to a live Skype session with all parents and a letter for those who missed it, discussing moving forward with COVID19 in our school. I would do one live session via Skype or Zoom on a weekly basis with each child. I developed my own virtual programme and send [sent] this out four days a week. I recorded a morning 
ring for four days a week for pupils to watch via Google Classroom. I continue to do this. When I started teaching in May I taught online sessions from 1:30 to 2pm to pupils not returned and [provided the] virtual programme. From June I only teach and do online [sessions] in the afternoons for aftercare pupils who need homework supervision or lessons taught on a one-on-one basis. However, the effect of COVID-19 was that even though I can officially have 15 pupils on my premises, I have dropped the number to 10 pupils for 2020. This is not a financially viable option for a single income.

Mrs Purple's last sentence portrays how this principal is trying to retain her parents and children by providing online teaching activities, as this is her only means of income. This shows the desperate need to keep her ECD centre running as it was her only means of survival. Contextually, this principal is able to keep her head above the water as she resides in an urban area. She has designed four virtual rings for her children and has sent these out to parents for a 4-day week. Parents have access to computers and network and could thus keep in touch.

Although this principal had no TERS funding, she was able to buy a grocery hamper for her staff. More than that, she also realised the importance of her staff member and financially supported her. Her responsive leadership skills also allowed her to identify development opportunities for the children in her school. When she saw a large number of stimulation activities for children available online, she shared them with the parents of the children in her centre. She also recorded her morning rings for children to watch on Google Classroom and have related discussions with their parents. Mrs Purple exhibited contextually-responsive leadership skills. Of particular interest was the way she pushed back and re-shaped the contextual factors (financial constraints and providing instruments and ideas for learning), rather than 'considering them immutable factors destined to constrain their leadership practices and the learning environment' (Bredeson et al. 2011: 4).

\section{Discussion}

\section{Government's Lack of Response to the ECD Sector}

Due to the scarce literature that was available regarding the COVID-19 pandemic and its effect on the ECD centre, I utilised media reports and 
articles in the literature review. The main themes that emerged were: 1) utter disregard for ECD from the government during the COVID-19 lockdown; 2) complicated registration process for ECD centres; 3) the lack of professionalisation of the ECD sector; 4) a sigh of relief for the ECD workforce; and 5) the ECD Reform Movement. The themes summarise the neglect by the government but also underscored the challenges that ECD centre operators faced during COVID-19 and the hope for the ECD centres with the ECD Reform Movement.

\section{Differences in the Context-responsive Leadership between the Rural and Urban Principals}

Despite their challenges, the two principals of urban ECD centres responded to and shaped the context of the education and stimulation for children according to the COVID-19 situation. The two urban centre principals, Ms Green and Purple, immediately initiated Google Classroom content and WhatsApp communication with parents. In so doing, their constant communication built up a trust relationship during the COVID-19 lockdown. Hence, when schools re-opened, most of the children returned. However, the two rural school principals, Ms White and Yellow, felt vulnerable, financially insecure and feared their lack of understanding of the novel coronavirus. This led to no children returning to their centres after the re-opening of centres was announced. They thus suffered from a loss of livelihood. They feared the COVID-19 procedures and did not contact other centres for support. Their centres were doomed to closure. The differences could also have been linked to the fact that the two urban principals were older, more experienced and were in well-resourced environments where parents had access to technology and internet connections, whereas Ms White and Yellow had centres in deprived areas where technology was a luxury and survival was a constant struggle. Jansen (2020: 172) describes this heartrending problem as 'the pain of choosing between bread and data'.

As indicated by Hujala et al. (2016), ECD principals are important in facilitating conducive working conditions. Thus, they need to be regulated through the development of administrative and management systems. In South Africa, there are guidelines for ECD services in administering and managing effective running of ECD centres by the ECD centre principals (Atmore 2013). The ECD centres are required by the DSD to adhere to 
minimum standards in following specific processes and structures (Atmore 2013). According to the United Nations Children's Fund (UNICEF) (2010), community-based ECD centres in South Africa are less advantaged in financial management and governance than those from registered centres. For this reason, it is evident that there is a lack of support for the ECD principals in the disadvantaged communities in administering and managing ECD facilities in South Africa due to the registration requirements of ECD centres. The rural centres complained that there was lack of governmental support after the COVID-19 lockdown. Therefore, quality and working conditions conducive to implementing ECD services by ECD principals were compromised (Atmore 2013).

\section{Financial Challenges}

Rural centres were disadvantaged and un-registered. They did not receive any support from TERS and were forced to close down. The COVID-19 pandemic had the worst impact on the rural ECD centres, leading to closures, parents' loss of jobs and income, and most importantly, babies and children in the birth to 4-year age category being without adequate stimulation. The victims of the lack of government responsibility to ECD centres were undoubtedly the rural ECD centres. Although ECD was treated with utter disrespect and care from the departments responsible for it, the ECD community protested and had their voices heard. There has been a slight movement from the government to repair the destruction of the ECD workforce (DoMore Foundation 2020). As mentioned, this is only R760 per person per month, but a welcome relief for most practitioners who were not even paid their stipends during the COVID-19 lockdown months.

The registered urban centre was able to respond appropriately to the closure by providing support to staff and parents; however, the unregistered urban centre was not supported by the TERS fund. This resulted in loss of income and fewer children returning after the COVID-19 reopening. However, it was clear that the context of the principals dictated their actions and the re-opening of their centres. The unregistered urban centre principal responded appropriately by providing her staff member with a grocery hamper for the lockdown months when children were not at school. This gesture led to a relationship beyond professional boundaries and earned her more commitment from her staff towards the care of the children in the 
centre. Unfortunately, the vignettes show that the rural centres were severely affected and that the financial cuts and lack of support led to closure of the centres. Principals in rural centres did not adapt to the new environment as they had no means to operating in a technologically advantaged arena. They were aware that in their low socio-economic societies, the struggle for survival overshadowed the need for education for their children.

Research indicates that there is little integration in the sharing of roles and responsibilities by different government department levels (National, Provincial and Regional) in funding, monitoring and supporting ECD centres and that the quality of services delivered is compromised (Richter et al. 2015). Hence, the South African government, through its policies should ensure that their leadership practices address the country's peculiar contextual challenges, especially the diverse socio-economic challenges and conditions faced by the early childhood education sector. Most rural centres are un-registered and struggle to achieve the requirements for being registered. It is hoped that the five reforms that ECD practitioners have called for will receive some response from the government department soon.

\section{Conclusion}

The study accentuated the lack of responsiveness from the government departments towards the ECD sector and the context- responsive leadership behaviour of principals in rural and urban centres. Although the rural ECD practitioners were severely affected, their campaigns and protests did not go unnoticed and there was monetary relief to provide some compensation. COVID-19 certainly highlighted the plight of ECD workers in rural areas. Whether the funds reach the correct people, remains to be seen. However, policy regarding ECD needs to be supported with a practical plan by the government. Fortunately, while this article was being written, the ECD reform petition was drawn up. This could prove to be a practical plan, if all the ECD governmental stakeholders work together in realising their roles and responsibilities. The departments responsible for the support and monitoring of ECD centres need to embrace their responsibilities and understand the urgency of the situation when dealing with vulnerable young children. Departmental stakeholders need to be trained on relevant pedagogy and resources required. Building partnerships with parents has become crucial during this pandemic, and when teachers were proactive in ensuring com- 
munication and providing stimulation activities for child development, parents felt valued and included. In fact, COVID-19 has allowed parents to begin to play a responsive role in the development of their children in the two urban centres. However, the clear demarcation between the 'haves' and the 'have nots' was glaring. The rural ECD centre principals had resigned themselves to an 'I don't know what to do' attitude. This magnifies the government's role to invest in infrastructure that serves the low socioeconomic societies and ensure the availability of online training, data and devices. While the study's design (four ECD centres) may limit the strength of the conclusion that can be drawn about the difference between the rural and urban centres, its use of narratives in sharing challenges during COVID19 provides substantial evidence of the social injustice and inequity, and the need for more support for rural ECD centres. If ECD is the great 'equaliser', it has become more urgent than ever to provide more financial, capacity building and infrastructural support to rural ECD centres.

\section{Acknowledgement:}

Prof. Eric Atmore, for sharing ideas and articles about the ECD sector.

\section{References}

Adeleke, A.G. 2020. Home Education as Alternative to Institutional Schooling in Nigeria: Lessons from COVID-19. International Studies in Educational Administration 48,1: 66 - 71.

Almanthari, A., S. Maulina \& S. Bruce 2020. Secondary School Mathematics Teachers' Views on E-learning Implementation Barriers during the COVID-19 Pandemic: The Case of Indonesia. Eurasia Journal of Mathematics, Science and Technology Education 16, 7: 1 -9. Available at: https://www.ejmste.com/article/secondary-school-mathematicsteachers-views-on-e-learning-implementation-barriers-during-the-8240 (Accessed on 20 August 2020.) https://doi.org/10.29333/ejmste/8240

Atmore, E. 2013. Early Childhood Development in South Africa - Progress since the End of Apartheid. International Journal of Early Years Education 21,2-3: 152 - 162. Available at: https://www.tandfonline.com/doi/abs/10.1080/09669760.2013.832941 (Accessed on 24 November 2021.) https://doi.org/10.1080/09669760.2013.832941 
Atmore, E. 2021. It's Election Time, and Politicians will be Kissing Babies - Yet their Silence on Early Childhood Development is Deafening.

Available at: https://www.dailymaverick.co.za/opinionista/2021-1005-its-election-time-and-politicians-will-be-kissing-babies

(Accessed on 24 November 2021.)

Atmore, E., L. van Niekerk, M. Ashley-Cooper 2012. Challenges Facing the Early Childhood Development Sector in South Africa. South African Journal of Childhood Education 2,1: 120 - 139. Available at:

https://eric.ed.gov/?id=EJ1187223

(Accessed on 24 November 2021.)

https://doi.org/10.4102/sajce.v2i1.25

Baloyi, T.V. \& J.C. Makhubela. 2018. Challenges Impeding the Successful Implementation of Early Childhood Development Programmes in South Africa: Implications for Practice. Gender \& Behaviour 16,1,June: 10773 - 10783. Available at:

http://ulspace.ul.ac.za/bitstream/handle/10386/3034/makhubele challe nges 2018.pdf? sequence $=1 \&$ isAllowed $=y$

(Accessed on 23 November 2021.)

Bassingthwaighte, A. 2020. Covid-19 Lockdown: Government's Failure to Lead the ECD Sector Needs to be Addressed. Available at: https://www.iol.co.za/news/opinion/covid-19-lockdown-governmentsfailure-to-lead-the-ecd-sector-needs-to-be-addressed-49859881

(Accessed on 20 August 2020.)

Berry, L., L. Biersteker, H. Dawes, L. Lake \& C. Smith (eds.). 2013. The South African Child Gauge. Children's Institute, University of Cape Town. Available at:

http://www.ci.uct.ac.za/sites/default/files/image_tool/images/367/Chil d Gauge/South African Child Gauge 2013/Gauge2013OverviewPar t2.pdf (Accessed on 20 August 2020.)

Bipath, K. \& I. Joubert 2016. Birth of a New Curriculum for ECD. Mail and Guardian 27 May 2016: 4. Available at:

https://mg.co.za/article/2016-05-27-00-the-birth-of-a-newqualification-for-ecd/ (Accessed on 20 August 2020.)

Bradbury-Jones C., J. Taylor, O.R. Herbert 2014. Vignette Development and Administration: A Framework for Protecting Research Participants. International Journal of Social Research Methodology 17,2: 427 - 440. https://www.tandfonline.com/doi/abs/10.1080/13645579.2012.750833 
(Accessed on 20 August 2020.)

https://doi.org/10.1080/13645579.2012.750833

Bredeson, P.V., H.W. Klar \& O. Johansson 2011. Context Responsive Leadership: Examining Superintendent Leadership in Context. Education Policy Analysis Archives 19: 18.

http://dx.doi.org/10.14507/epaa.v19n18.2011

(Accessed on 20 August 2020.)

BRIDGE, Ilifa Labantwana, National ECD Alliance (NECDA), the Nelson

Mandela Foundation, Smartstart and the South African Congress for

Early Childhood Development (SACECD) 2020. The Plight of the ECD Workforce. Available at:

https://www.bridge.org.za/wp-content/uploads/2020/04/Final-report-

The-plight-of-the-ECD-workforce-1.pdf

Coulter, C.A. \& M.L. Smith 2009. The Construction Zone: Literary Elements in Narrative Research. Educational Researcher 38,8: 577 - 590.

Available at:

https://journals.sagepub.com/doi/abs/10.3102/0013189x09353787

(Accessed on 24 November 2020.)

https://doi.org/10.3102/0013189X09353787

Caine, V., A. Estefan \& D.J. Clandinin 2013. A Return to Methodological Commitment: Reflections on Narrative Inquiry. Scandinavian Journal of Educational Research 57,6: 574 - 586. Available at:

https://www.tandfonline.com/doi/abs/10.1080/00313831.2013.798833 https://doi.org/10.1080/00313831.2013.798833

Davids, M., M.L. Samuels, R. September, T.L. Moeng, L. Richter, T.W. Mabogoane, I. Goldman \& T. Buthelezi 2015. The Pilot Evaluation for the National Evaluation 224 System in South Africa: A Diagnostic Review of Early Childhood Development. African Evaluation Journal 3, 1. Art\#141. Available at: https://doi.org/10.4102/aej.v3i1.141 (Accessed on 20 August 2020.)

Department of Education (DoE) 2001. Report on the National Early Childhood Development Pilot Project. Department of Education.

Available at:

https://www.westerncape.gov.za/text/2003/national report ecd pilot $\underline{\text { 2001.pdf }}$

Department of Social Development (DSD) 2015. National Integrated Early Childhood Development Policy. Pretoria: Government Printers. 
Available at:

https://www.gov.za/sites/default/files/gcis_document/201610/nationalintegrated-ecd-policy-web-version-final-01-08-2016a.pdf

(Accessed on 20 August 2020.).

Department of Social Development (DSD) 2020. Social Development Sets Up Workstreams to Conduct Risk Assessment and State of Readiness for the Early Childhood Development (|ECD) Centres. Available at: https://www.dsd.gov.za/index.php/latest-news/21-latest-news/183social-development-sets-up-workstreams-to-conduct-risk-assessmentand-state-of-readiness-for-the-early-childhood-development-ecdcentres (Accessed on 22 November 2021.)

DoMore Foundation, 27 April 2020. We Call on Government to Support the Early Childhood Development (ECD) Sector. Available at: https://domore.org.za/2020/04/27/we-call-on-government-to-supportthe-early-childhood-development-ecd-sector/ (Accessed on 18 August 2020.)

DoMore Foundation, 23 October 2020. Signs of Relief for Early Childhood Development. Available at:

https://domore.org.za/2020/10/23/signs-of-relief-for-early-childhooddevelopment/ (Accessed 22 November 2020.)

Dwyer, R. \& E. Emerald 2017. Narrative Research in Practice: Navigating the Terrain. In Dwyer, R. I. Davi \& E. Emerald (eds.): Narrative Research in Practice: Stories from the Field. Dordrecht, Netherlands: Springer. https://doi.org/10.1007/978-981-10-1579-3

https://link.springer.com/chapter/10.1007/978-981-10-1579-3_1

Equal Education 2009. Comment on Regulations Relating to the Prohibition of the Payment of Unauthorised Remuneration of the Giving of Financial Benefit or Benefit in Kind to Certain State Employees. Khayelitsha, Cape Town: Equal Education.

https://link.springer.com/chapter/10.1007/978-981-10-1579-3 1

Farber, T. 2020. Covid-19 Lockdown a Disaster for Children's Growth as Poverty Deepens. Available at:

https://www.dispatchlive.co.za/news/2020-09-23-covid-19-lockdowna-disaster-for-childrens-growth-as-poverty-deepens/ (Accessed on 18 August 2020.).

Fortuna, L.R., M. Tolou-Shams \& B. Robles-Ramamurthy 2020. Inequity and the Disproportionate Impact of COVID-19 on Communities of 
Color in the United States: The Need for a Trauma-Informed Social Justice Response. Trauma Psychology 12, 5: 443 - 445. Available at: http://dx.doi.org/10.1037/tra0000889 (Accessed 24 November 2020.) PMid:32478545 PMCid:PMC8243721

Finch, J. 1987. The Vignette Technique in Survey Research. Sociology 21,1: 105 - 114. Available at:

https://journals.sagepub.com/doi/abs/10.1177/0038038587021001008 (Accessed 24 November 2020.)

Hallinger, P. 2016. Bringing Context Out of the Shadows of Leadership. Educational Management Administration \& Leadership 46,1: 5 - 24. https://doi/org/10.1177/1741143216670652

Hujala, E., M. Eskelinen, S. Keskinen, C. Chen, C. Inoue, M. Matsumoto \& M. Kawase 2016. Leadership Tasks in Early Childhood Education in Finland, Japan, and Singapore. Journal of Research in Childhood Education 30,3: 406 - 421.

https://doi.org/10.1080/02568543.2016.1179551

Jansen. J. 2020. Data or Bread? A Policy Analysis of Student Experiences under Lockdown. South African Review of Education 26,1: 167 - 181.

Available at:

https://journals.co.za/doi/abs/10.10520/ejc-sare-v26-n1-a11

(Accessed 24 November 2020.)

Leshoele, M. 2016. Implications of Public Funding for Early Learning in South Africa: A Case of Ekurhuleni Metropolitan Municipality in Gauteng. Unpublished MEd thesis. Witwatersrand University. Available at: https://scholar.google.co.za/citations?user=5QYvBDsAAAAJ\&hl=en (Accessed 24 November 2021.)

Louis, K.S., K. Leithwood, K.L. Wahlstrom \& S.E. Anderson 2010. Learning from Leadership: Investigating the Links to Improved Student Learning. New York: University of Minnesota, Center for Applied Research and Educational Improvement.

https://www.wallacefoundation.org/knowledge-

center/pages/investigating-the-links-to-improved-student-learning.aspx (Accessed on 24 November 2021.)

Mbarathi, N., M.E. Mthembu \& K. Diga 2016. Early Childhood Development and South Africa: A Literature Review. Technical paper no 6. University of KwaZulu-Natal, South Africa. Available from: https://ukzn-dspace.ukzn.ac.za/handle/10413/13338 
(Accessed on 24 November 2021.)

Mndende, A. 2020. Unhappy ECD Practitioners Call on Parliament for

Reform. Available at: https://www.news24.com/parent/learn/primary-

school/unhappy-ecd-practitioners-call-on-parliament-for-reform-

20201027 (Accessed on 19 January 2021.)

Noman, M., R.A. Hashim \& S.S. Abdulla. 2018. Contextual Leadership

Practices: The Case of a Successful School Principal in Malaysia.

Educational Management Administration \& Leadership 46,3: 474 -

490. Available at: https://doi.org/10.1177/1741143216665840

https://journals.sagepub.com/doi/abs/10.1177/1741143216665840

(Accessed at 24 November 2021.)

Polkinghorne, D. 1995. Narrative Configuration in Qualitative Analysis. In

Hatch, J. \& R. Wisniewski (eds.): Life History and Narrative. London:

The Falmer Press.

https://www.tandfonline.com/doi/abs/10.1080/0951839950080103

Prochner, L. \& M. Kabiru. 2008. ECD in Africa: A Historical Perspective.

In Garcia. M., A. Pence \& J.L. Evans (eds.): Africa's Future, Africa's

Challenge: Early Childhood Care and Development in Sub-Saharan

Africa. The World Bank.

https://books.google.co.za/books

Real Reform for ECD 2020. Available at:

https://www.change.org/p/hon-mondi-gungubele-real-reform-for-ecd-

4af73254-9584-4f5c-b1d3-e11e85679c3e?redirect=false

(Accessed on 8 January 2020.)

Richter, L., L. Biersteker, J. Burns, C. Desmond, N. Feza, D. Harrison, W.

Slemming 2012. Diagnostic Review of Early Childhood Development.

Report for Department of Performance Monitoring and Evaluation (DPME) in the Presidency. Available at:

https://static.pmg.org.za/130618diagnostic_report.pdf

(Accessed at 24 November 2021.)

Republic of South Africa (RSA) 2007. Children's Amendment Act, No. 41 of 2007. Government Gazette, 513(30884). Pretoria: Government Printer.

Available at:

https://www.parliament.gov.za/storage/app/media/Docs/acts/616504 1 .pdf (Accessed at 24 November 2021.)

Republic of South Africa (RSA) 1996. The Constitution of the Republic of South Africa. Pretoria: Government Printers. Available at: 
https://www.gov.za/sites/default/files/images/a108-96.pdf

(Accessed at 24 November 2021.)

Spaull, N. \& S. van der Berg 2020. Counting the Cost: COVID-19 School

Closures in South Africa and its Impact on Children. South African Journal of Childhood Education 10,1: a924. Available at:

https://doi.org/10.4102/ sajce.v10i1.924

(Accessed at 24 November 2021.)

Torres S. 2009. Vignette Methodology and Culture-relevance: Lessons

Learned through a Project on Successful Aging with Iranian Immigrants to Sweden. Journal of Cross-Cultural Gerontology 24,1:93 - 114.

https://link.springer.com/article/10.1007/s10823-009-9095-9

(Accessed at 24 November 2021.)

https://doi.org/10.1007/s10823-009-9095-9

PMid:19199017

Wallander L. 2009. 25 Years of Factorial Surveys in Sociology: A Review. Social Science Research 38,3: 505 - 520. Available at:

https://www.sciencedirect.com/science/article/abs/pii/S0049089X0900 $\underline{0192}$ (Accessed at 24 November 2021.)

https://doi.org/10.1016/j.ssresearch.2009.03.004

United States Department of Health and Human Services. 2010. Head Start Impact Study Final Report: Executive Summary. Washington, DC: United States Department of Health and Human Services. Available at: https://www.acf.hhs.gov/opre/report/head-start-impact-study-finalreport-executive-summary (Accessed at 24 November 2021)

Urban, M. 2014. Zones of Professional Development: Arguments for Reclaiming Practice-based Evidence in Early Childhood Practice and Research. In Hayden, J. \& A. Tuna (eds.): Moving Forward Together: Early Childhood Programs as the Doorway to Social Cohesion: An East-West Perspective. Newcastle upon Tyne: Cambridge Scholars. Available at:

https://pure.roehampton.ac.uk/portal/en/publications/zones-ofprofessional-development-arguments-for-reclaiming-practi (Accessed at 24 November 2021.)

Vorster, R.W. 2020. Can South Africa's Early Childhood Development Sector be Saved. Available at:

https://www.dailymaverick.co.za/opinionista/2020-06-23-can-southafricas-early-childhood-development-sector-be-saved/ 
(Accessed on 19 ${ }^{\text {th }}$ August 2020.)

Yoshikawa, H., A.J. Wuermli, P.R. Britto, B. Dreyer, J.F. Leckman, S.J. Lye, L.A. Ponguta, L.M. Richter \& A. Stein 2020. Effects of the Global COVID-19 Pandemic on Early Childhood Development: Short- and Long-term Risks and Mitigating Program and Policy Actions. The Journal of Pediatrics 233: 188-193. Available at:

https://www.jpeds.com/article/S0022-3476(20)30606-5/fulltext

(Accessed at 24 November 2021.)

https://doi.org/10.1016/j.jpeds.2020.05.020

PMid:32439312 PMCid:PMC7234941

Professor Keshni Bipath

University of Pretoria keshni.bipath@up.ac.za

Dr. Adebunmi Yetunde Aina

University of Pretoria 